\title{
Olivibacter sitiensis gen. nov., sp. nov., isolated from alkaline olive-oil mill wastes in the region of Sitia, Crete
}

Correspondence

Georgios I. Zervakis

zervakis@kal.forthnet.gr

\author{
Spyridon Ntougias, ${ }^{1}$ Constantinos Fasseas ${ }^{2}$ and Georgios I. Zervakis ${ }^{1}$
}

\author{
${ }^{1}$ National Agricultural Research Foundation, Institute of Kalamata, Lakonikis 87, \\ 24100 Kalamata, Greece \\ ${ }^{2}$ Agricultural University of Athens, Department of Agricultural Biotechnology, Electron \\ Microscopy Laboratory, lera Odos 75, 11855 Athens, Greece
}

At the time of writing, the family Sphingobacteriaceae consists of the genera Sphingobacterium and Pedobacter (Steyn et al., 1998). The genus Sphingobacterium includes the following recognized species: Sphingobacterium antarcticum (the corrected name of S. antarcticus), S. faecium, S. multivorum, S. spiritivorum and S. thalpophilum (Yabuuchi et al., 1983; Shivaji et al., 1992; Takeuchi \& Yokota, 1992). Steyn et al. (1998) erected the genus Pedobacter initially to accommodate the species Pedobacter africanus, $P$. heparinus, $P$. piscium and $P$. saltans; seven further species, Pedobacter caeni, P. cryoconitis, $P$. himalayensis, $P$. sandarakinus, $P$. aquatilis, $P$. ginsengisoli and $P$. roseus have since

\section{Abbreviation: ECL, equivalent chain-length.}

The GenBank/EMBL/DDBJ accession number for the 16S rRNA gene sequence of strain $\mathrm{AW}-6^{\top}$ is $\mathrm{DQ} 421387$.

An electron micrograph showing the cell morphology of strain AW-6 ${ }^{\top}$ and a dendrogram based on data for 40 physiological and chemotaxonomic characteristics of strain $A W-6^{\top}$, members of the genera Sphingobacterium and Pedobacter and Flavobacterium mizutaii are available as supplementary material in IJSEM Online. been added (Margesin et al., 2003; Shivaji et al., 2005; Vanparys et al., 2005; Gallego et al., 2006; Hwang et al., 2006; Ten et al., 2006; Yoon et al., 2006).

Only a few bacteria isolated from olive-processing products and residues have been recognized (Chamkha et al., 2001; Koussemon et al., 2001). Alkalibacterium (Ntougias \& Russell, 2001) and Sporobacterium (Mechichi et al., 1999) are the only currently recognized genera; their type species, Alkalibacterium olivapovliticus and Sporobacterium olearium, were isolated from edible-olive wash-water and from an olive mill wastewater treatment digester, respectively. Alpeorujo is a liquid-solid waste produced by two-phase olive-oil decanters which is usually amended (before disposal) by $\mathrm{Ca}(\mathrm{OH})_{2}$ to generate a moderately alkaline secondary waste (alkaline alpeorujo). To date, the only bacterial isolates recovered from alkaline alpeorujo have been either halotolerant alkaliphilic or halotolerant/alkalitolerant micro-organisms (Ntougias et al., 2006).

Here, we describe the morphological, physiological, chemotaxonomic and phylogenetic characteristics of a novel, 
non-halotolerant, non-alkalitolerant bacterium isolated from alkaline alpeorujo. Based on its unique taxonomic properties, we conclude that this isolate, designated strain AW $-6^{\mathrm{T}}$, represents a novel species of a new bacterial genus.

Bacterial strain $\mathrm{AW}-6^{\mathrm{T}}$ was isolated from alkaline alpeorujo, an olive by-product produced by an olive-oil mill equipped with a two-phase centrifugal system located at the premises of the Toplou Monastery, Sitia $\left(35^{\circ} 13^{\prime} 12^{\prime \prime} \mathrm{N}\right.$ $26^{\circ} 6^{\prime} 6^{\prime \prime} \mathrm{E}$ ), north-east Crete, Greece. Alpeorujo, amended with $0.7 \%$ w/w $\mathrm{Ca}(\mathrm{OH})_{2}$, was obtained from an open-air settling pond near the olive-oil mill. The $\mathrm{pH}$ and the electrical conductivity of the alkaline alpeorujo (diluted in water at a volume ratio of $1: 1)$ were 8.7 and $16.2 \mathrm{mS} \mathrm{cm}^{-1}$, respectively.

For isolation, a $10 \mathrm{~g}$ sample of alkaline alpeorujo was mixed with $100 \mathrm{ml} \mathrm{NaCl}$ solution $\left(8.5 \mathrm{~g} \mathrm{l}^{-1}\right)$ followed by a tenfold dilution series (Ntougias et al., 2006). Extract from alkaline alpeorujo (100 g per 1 litre of distilled water, stirred for 20 min, filtered and adjusted to $\mathrm{pH}$ 7) solidified with agar was used as the isolation medium (Ntougias et al., 2006). After incubation for 1 week at $25^{\circ} \mathrm{C}$, bacterial isolate AW- $6^{\mathrm{T}}$ was obtained and subcultured on solid medium (by the addition of $17 \mathrm{~g}_{\text {agar }} \mathrm{l}^{-1}$ ) containing $10 \mathrm{~g}$ glucose $\mathrm{l}^{-1}, 5 \mathrm{~g}$ yeast extract $1^{-1}, 5 \mathrm{~g}$ peptone $\mathrm{l}^{-1}, 0.1 \mathrm{mM} \mathrm{MgSO}_{4}$ and phosphate buffer at $\mathrm{pH} 7$ (Ntougias et al., 2006). Bacterial growth for maintenance (glycerol stocks or slants) was carried out at $25^{\circ} \mathrm{C}$ (temperature of isolation), while the experimental temperature for growth was $28{ }^{\circ} \mathrm{C}$ (optimal temperature). Strain AW- $6^{\mathrm{T}}$ was grown on the medium described above unless otherwise specified.

The $\mathrm{pH}$ range for growth (single unit steps from $\mathrm{pH} 4$ to 9) was examined by using the appropriate buffer solutions (Ntougias \& Russell, 2000). Salt tolerance was investigated in the presence of 0,30 and $50 \mathrm{~g} \mathrm{NaCll}^{-1}$. Bacterial substrate utilization was tested in media $(\mathrm{pH} 7$, with $\mathrm{pH}$ adjusted when necessary) containing a specific sugar, amino acid or other substrate (results are given in the species description below), $0.1 \mathrm{mM} \mathrm{MgSO} 4$ and $0.05 \mathrm{~g}$ yeast extract $\mathrm{l}^{-1}$ (no growth was observed in the medium containing the above concentration of yeast extract as the sole carbon source). The concentration of each compound tested was $0.05 \mathrm{M}$, unless the medium was saturated at a lower concentration, in which case a concentration up to the saturation point was used. The concentration of ethanol and glycerol was $0.5 \%$ $(\mathrm{v} / \mathrm{v})$ and $0.5 \mathrm{~g}$ phenol $1^{-1}$ was also tested. Salts, metabolic compounds, yeast extract and the buffer were sterilized separately and mixed aseptically. Sensitive compounds were filter-sterilized. Incubations were performed at 3, 5, 10, 15, $20,25,28,32,37,40,45$ and $50^{\circ} \mathrm{C}$ to investigate the temperature range for growth. Anaerobic growth was examined by using the Anaerocult A system (Merck). Antibiotic susceptibility was investigated on medium containing $50 \mu \mathrm{g} \mathrm{ml}^{-1}$ of the antibiotic tested (Ntougias et al., 2006). Tween hydrolysis, catalase- and oxidaseactivity, spore formation and Gram staining were also examined (Smibert \& Krieg, 1994).
For transmission electron microscopy, suspensions of bacterial cells were placed on pyroxyline-coated copper grids (AEI) and negatively stained with $1 \%(\mathrm{w} / \mathrm{v})$ phosphotungstic acid (pH 7.0) in water for $10 \mathrm{~s}$. Specimens were examined and photographed with a transmission electron microscope (9-S; Zeiss).

Genomic DNA was extracted according to Wilson (1992). The almost full-length 16S rRNA gene was amplified using universal primers $A_{\text {for }}$, 5'-GGAGAGTTAGATCTTGGCTCAG-3' (sense; positions 6-27 according to the Escherichia coli numbering system) and $\mathrm{C}_{\mathrm{rev}}, 5^{\prime}$-AGAAAGGAGGTGATCCAGCC-3' (antisense; positions 1542-1525). A reaction mixture $(50 \mu \mathrm{l})$ containing $1 \mu \mathrm{l}\left(50 \mathrm{ng} \mu^{-1}\right)$ genomic DNA, $10 \times$ PCR buffer (Finnzymes OY), $2 \mathrm{mM}$ $\mathrm{MgCl}_{2}, 200 \mu \mathrm{M}$ each dATP, dTTP, dCTP and dGTP, primers $A_{\text {for }}$ and $C_{\text {rev }}(0.5 \mu \mathrm{M}$ each $)$ and $1 \mathrm{U}$ DNA polymerase (Dynazyme EXT-Finnzymes OY) was prepared (Ntougias \& Russell, 2001). 16S rRNA gene amplification was performed by using a PTC-200 thermocycler (MJ Research Inc.) using a denaturation step of $2 \mathrm{~min}$ at $94^{\circ} \mathrm{C}$, followed by 35 cycles of $30 \mathrm{~s}$ denaturation at $94^{\circ} \mathrm{C}$, $30 \mathrm{~s}$ primer annealing at $55^{\circ} \mathrm{C}$ and $1 \mathrm{~min}$ DNA chain extension at $72{ }^{\circ} \mathrm{C}$. The PCR was terminated by 5 min DNA chain extension at $72^{\circ} \mathrm{C}$.

Three independent clones were obtained by cloning the respective amplicons in the pGEM-T Easy Vector (Promega) before insertion into DH5a competent cells. Plasmid DNA was purified by using the NucleoSpin plasmid Quick Pure kit (Macherey-Nagel). PCR sequencing using the fluorescence-labelled primers SP6 and T7 (Promega) and additional primers ( $5^{\prime}$-AGGCGGAATGAGGCAAGTAGC-3' and 5' $^{\prime}$-TGCCAGAGTCCCCACCATAAC-3') was performed at the Institute of Molecular Biology and Biotechnology (IMBB), Heraklion, Greece, via a LI-COR Long ReadIR2 4200 automated sequencer.

The 16S rRNA gene sequences were assembled using the DNAstar suite of programmes (DNAstar Inc.). Similarity searches were carried out by BLAST analysis (http:// www.ncbi.nlm.nih.gov/blast/) and the closest relatives to strain $\mathrm{AW}-6^{\mathrm{T}}$ were included in further phylogenetic analyses. Alignment of the sequences and phylogenetic tree construction were performed by using the CLUSTAL $\mathrm{W}$ Submission Form (http://www.ebi.ac.uk/clustalw/) and TREECON for Windows (version 1.3b) (Van de Peer \& de Wachter, 1993), respectively. Evolutionary distances were calculated according to Jukes \& Cantor (1969) and the topology was inferred using the neighbour-joining method (Saitou \& Nei, 1987) based on bootstrap analysis of 1000 trees. Phylogenetic trees were also generated by using the maximum-likelihood (DNAML; Cavalli-Sforza \& Edwards, 1967) and maximum-parsimony (DNAPARS; Kluge \& Farris, 1969) algorithms within the PHYLIP version 3.6 phylogenetic package (Felsenstein, 2004), including the SEQBOOT program for bootstrap analysis. Only almost full-length $16 \mathrm{~S}$ rRNA gene sequences were used for tree construction. The 
16S rRNA gene sequence (1477 bp) of strain $\mathrm{AW}-6^{\mathrm{T}}$ was deposited in the GenBank database.

Numerical analysis was performed using the NTSYSpc package (version 2.2 for Windows; Exeter Software) (Rohlf, 2000). A binary $0 / 1$ matrix was created based on the absence or presence, respectively, of physiological and chemotaxonomic characteristics. Similarities were calculated with the 'SimQual' option within NTSYSpc by employing the 'Simple Matching-SM' and the 'Jaccard-J' coefficients. For cluster analysis, the 'SAHN' option from the package was employed using the unweighted pair group method with arithmetic mean (UPGMA) for clustering.

Chemotaxonomic analyses (quinone and fatty acid methyl ester analyses), DNA-DNA hybridization experiments and DNA G $+\mathrm{C}$ content determination were carried out by the Identification Service of the Deutsche Sammlung von Mikroorganismen und Zellkulturen (DSMZ), Braunschweig, Germany. DNA for spectroscopic DNADNA hybridization experiments and $\mathrm{G}+\mathrm{C}$ content determination was isolated as described by Cashion et al. (1977). DNA-DNA hybridization experiments were performed as described by De Ley et al. (1970) and modified as suggested by Huß et al. (1983). DNA G + C content determination was carried out according to Tamaoka \& Komagata (1984) and Mesbah et al. (1989). Fatty acid methyl esters were obtained as described by Kroppenstedt (1985) and Kämpfer \& Kroppenstedt (1996) and by using minor modifications of the methods given by Miller (1982) and Kuykendall et al. (1988). Respiratory lipoquinone analyses were carried out by Dr B. J. Tindall and the Identification Service of the DSMZ according to a standard procedure (Tindall, 1990a, b).

Morphological, cultural, physiological and biochemical characteristics of strain $\mathrm{AW}-6^{\mathrm{T}}$ are given in the species description below. A transmission electron micrograph showing cell morphology is available as Supplementary Fig. S1 in IJSEM Online.

Only menaquinone-7 was detected in the respiratory chain of strain AW $-6^{\mathrm{T}}$. The detailed fatty acid profile of strain AW$6^{\mathrm{T}}$ was as follows: $\mathrm{C}_{16: 1} \omega 7 \mathrm{c}$ and/or iso- $\mathrm{C}_{15: 0} 2-\mathrm{OH}(43.2 \%)$, iso- $\mathrm{C}_{15: 0}(29.3 \%)$, iso- $\mathrm{C}_{17: 0} 3-\mathrm{OH}(11.2 \%), \mathrm{C}_{16: 0}(5.5 \%)$, iso- $\mathrm{C}_{17: 1} \omega 9 c(2.0 \%)$, iso- $\mathrm{C}_{15: 0} 3-\mathrm{OH}(1.9 \%), \mathrm{C}_{16: 1} \omega 5 c$ $(1.3 \%), 1.1 \%$ of an unknown fatty acid [equivalent chain length (ECL) of 16.582 as calculated by the Sherlock Microbial Identification System version 4.5], $\mathrm{C}_{16: 0} 2-\mathrm{OH}$ $(0.9 \%), 0.9 \%$ of an unknown fatty acid (ECL of 13.565), $\mathrm{C}_{16: 0} 3-\mathrm{OH}(0.7 \%), \mathrm{C}_{16: 1} 2-\mathrm{OH}(0.6 \%), \mathrm{C}_{14: 0}(0.5 \%)$, anteiso $\mathrm{B}$ and/or iso $\mathrm{I}_{17: 1}(0.5 \%)$, iso- $\mathrm{C}_{17: 0}(0.4 \%)$, and iso $\mathrm{FC}_{15: 1}(0.3 \%)$.

The phylogenetic placement of strain AW- $6^{\mathrm{T}}$ among members of the family Sphingobacteriaceace is illustrated in Fig. 1. Based on 16S rRNA gene sequence analysis, strain AW $-6^{\mathrm{T}}$ was associated, but not closely, with members of the genera Sphingobacterium and Pedobacter within this family. Its closest relatives, but still distinct from strain $\mathrm{AW}-6^{\mathrm{T}}$, were clone BIti35 (89.7\% 16S rRNA gene sequence similarity) and Sphingobacterium daejeonense ( $89.7 \%$ similarity), while all recognized members of the genera Sphingobacterium and Pedobacter were placed in separate phylogenetic clusters. S.

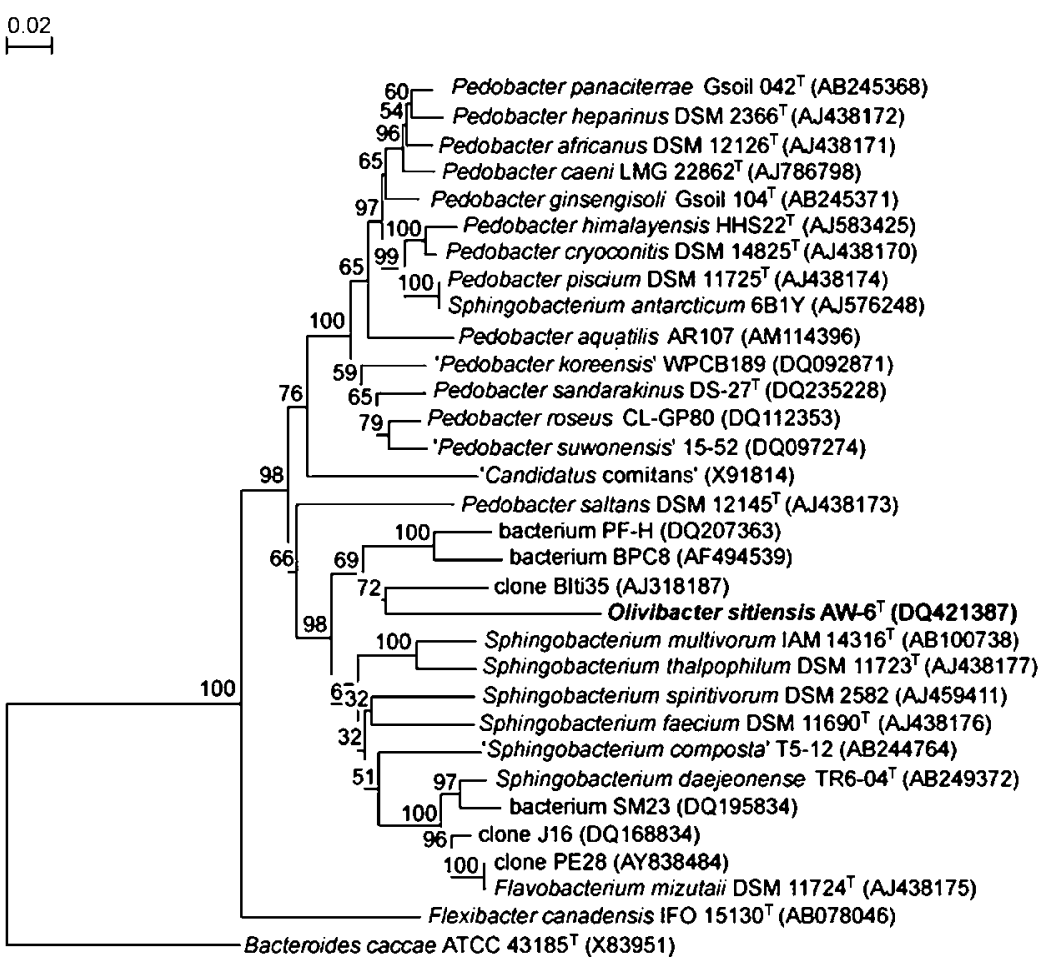

Fig. 1. Phylogenetic position of strain $A W-6^{\top}$ and members of the family Sphingobacteriaceae based on 16S rRNA gene sequence analysis. Evolutionary distances were calculated using the method of Jukes \& Cantor (1969) and the topology was inferred using the neighbour-joining method (Saitou \& Nei, 1987) based on bootstrap analysis of 1000 trees. The $16 \mathrm{~S}$ rRNA gene sequence of Bacteroides caccae ATCC $43185^{\top}$ was arbitrarily chosen as the outgroup. Bar, 0.02 substitutions per site. 
thalpophilum DSM $11723^{\mathrm{T}}$ was the closest recognized relative within the Sphingobacteriaceae ( $88.2 \%$ similarity).

The DNA G + C content of strain AW $-6^{\mathrm{T}}$ was $45.6 \mathrm{~mol} \%$. Levels of DNA-DNA relatedness between strain AW- $-6^{\mathrm{T}}$ and S. thalpophilum DSM $11723^{\mathrm{T}}$ were $33.8-37.0 \%$.

In contrast to $S$. thalpophilum (its closest relative within the genus Sphingobacterium), strain AW-6 ${ }^{\mathrm{T}}$ utilized L-cysteine, L-histidine and sorbitol, but not $\mathrm{D}(+)$-cellobiose, glycerol, maltose or starch. Moreover, strain AW- $6^{\mathrm{T}}$ contained iso $\mathrm{F}$ $\mathrm{C}_{15: 1}, \mathrm{C}_{16: 1} \quad 2-\mathrm{OH}, \mathrm{C}_{16: 1} \omega 5 c$, iso- $\mathrm{C}_{17: 0}$, iso- $\mathrm{C}_{17: 1} \omega 9 c$, anteiso $B$ and/or iso $I C_{17: 1}$ and an unknown fatty acid (ECL of 16.580). A slightly greater DNA G $+C$ content for strain AW- $6^{\mathrm{T}}$ was also detected compared with $S$. thalpophilum (Takeuchi \& Yokota, 1992; Steyn et al., 1998). In contrast to Pedobacter saltans (its closest relative in the genus Pedobacter), strain $\mathrm{AW}-6^{\mathrm{T}}$ was able to grow at $42{ }^{\circ} \mathrm{C}$ and utilized L-cysteine, L-histidine and sorbitol, but not glycerol or maltose. In addition, strain $\mathrm{AW}-6^{\mathrm{T}}$ possessed iso $\mathrm{FC}_{15: 1}, \mathrm{C}_{16: 1} 2-\mathrm{OH}$, iso- $\mathrm{C}_{17: 0}$ and anteiso $\mathrm{B}$ and/or iso I $\mathrm{C}_{17: 1}$, but lacked anteiso- $\mathrm{C}_{15: 0}$. A higher DNA G+C content $(>8.5 \mathrm{~mol} \%$ greater) was also determined for strain AW- $6^{\mathrm{T}}$ compared with $P$. saltans (Steyn et al., 1998).

Differential physiological and chemotaxonomic characteristics between strain AW- $6^{\mathrm{T}}$ and members of the genera Sphingobacterium and Pedobacter are presented in Table 1.
In contrast to members of the genus Sphingobacterium (excluding S. antarcticum isolates), strain AW- $6^{\mathrm{T}}$ utilized Lcysteine and sorbitol, but not starch, $\mathrm{D}(+)$-cellobiose or maltose. Strain $\mathrm{AW}-6^{\mathrm{T}}$ was distinct from all members of the family Sphingobacteriaceae in terms of its inability to utilize maltose and its ability to grow at $42{ }^{\circ} \mathrm{C}$ (apart from $S$. thalpophilum, which also grows at $42^{\circ} \mathrm{C}$ ). The major fatty acids of all members of the family Sphingobacteriaceae were iso- $\mathrm{C}_{15: 0}$, iso- $\mathrm{C}_{15: 0} 2-\mathrm{OH}, \mathrm{C}_{16: 1} \omega 7 c$ and iso- $\mathrm{C}_{17: 0} 3-\mathrm{OH}$ (Steyn et al., 1998; Margesin et al., 2003; Shivaji et al., 2005; Vanparys et al., 2005; Yoon et al., 2006). However, differences in the presence or absence of minor fatty acid components were identified between strain $\mathrm{AW}-6^{\mathrm{T}}$ and members of the genera Pedobacter and Sphingobacterium (Table 1). Strain AW- $6^{\mathrm{T}}$ can be differentiated from Sphingobacterium and Pedobacter by the possession of

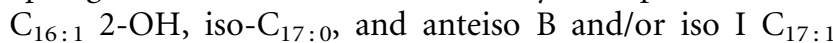
(Table 1). Moreover, iso $\mathrm{F} \mathrm{C}_{15.1}$ was detected in cells of strain AW-6 ${ }^{\mathrm{T}}$, but was absent from members of the genus Sphingobacterium. Combined physiological and chemotaxonomic data for strain AW- $6^{\mathrm{T}}$ distinguish it from members of the genera Pedobacter and Sphingobacterium, as is evidenced by its placement within a distinct cluster. A dendrogram based on combined physiological and chemotaxonomic data is available as Supplementary Fig. S2 in IJSEM Online. Levels of similarity between strain AW $-6^{\mathrm{T}}$ and recognized members of the family Sphingobacteriaceae

Table 1. Physiological and chemotaxonomic characteristics that differentiate strain $A W-6^{\top}$ from members of the genera Sphingobacterium and Pedobacter

Data for the genus Sphingobacterium are taken from Steyn et al. (1998). Data for the genus Pedobacter are taken from Steyn et al. (1998), Margesin et al. (2003), Shivaji et al. (2005), Vanparys et al. (2005) and Yoon et al. (2006). In all studies, cells for fatty acid methyl ester analysis were grown in peptoneyeast extract media at $28-30^{\circ} \mathrm{C}$. S. antarcticum was able to utilize sorbitol, but not starch although it was related to the genus Pedobacter rather than to the genus Sphingobacterium (see text, Fig. 1 and Supplementary Fig. S2 for details). +, Growth/presence; -, no growth/absence; v, variable.

\begin{tabular}{|c|c|c|c|}
\hline Characteristic & Strain AW- $6^{\mathrm{T}}$ & Sphingobacterium & Pedobacter \\
\hline Growth at $42^{\circ} \mathrm{C}$ & + & $\mathrm{V}$ & - \\
\hline \multicolumn{4}{|l|}{ Utilization of: } \\
\hline $\mathrm{D}(+)$-Cellobiose & - & + & $\mathrm{V}$ \\
\hline L-Cysteine & + & - & $\mathrm{V}$ \\
\hline L-Histidine & + & $-{ }^{\star}$ & $-\dagger$ \\
\hline Maltose & - & + & + \\
\hline Sorbitol & + & $-末$ & $\mathrm{~V}$ \\
\hline Starch & - & $+\ddagger$ & $\mathrm{V}$ \\
\hline \multicolumn{4}{|l|}{ Detection of fatty acids: } \\
\hline iso $\mathrm{F} \mathrm{C}_{15: 1}$ & $+(0.3 \%)$ & - & $\mathrm{V}(0-1.4 \%)$ \\
\hline $\mathrm{C}_{16: 1} 2-\mathrm{OH}$ & $+(0.6 \%)$ & - & - \\
\hline iso- $\mathrm{C}_{17: 0}$ & $+(0.4 \%)$ & - & - \\
\hline anteiso $\mathrm{B}$ /iso $\mathrm{I}^{\mathrm{C}_{17: 1}}$ & $+(0.5 \%)$ & - & - \\
\hline DNA G $+\mathrm{C}$ content $(\mathrm{mol} \%)$ & 45.6 & $37.3-44.2$ & $36.9-44.2$ \\
\hline
\end{tabular}

${ }^{*}$ Variable for members of the species S. multivorum.

$\dagger$ Variable for members of the species $P$. africanus.

$\ddagger$ Variable for members of the species $S$. antarcticum. 
were even lower when the 'Jaccard' rather than 'Simple Matching' coefficient was employed. Moreover, the separate generic position of strain AW- $6^{\mathrm{T}}$ in the tree constructed on the basis of physiological and chemotaxonomic data is in agreement with the phylogenetic tree (Fig. 1 and Supplementary Fig. S2).

Numerical analysis placed $P$. saltans in the cluster consisting of Sphingobacterium species (Supplementary Fig. S2); P. saltans was also grouped outside the cluster that included the remaining Pedobacter species in the phylogenetic tree (Fig. 1). Furthermore, based on physiological, chemotaxonomic and phylogenetic analysis, $S$. antarcticum was shown to be related to the genus Pedobacter rather than to the genus Sphingobacterium (Fig. 1 and Supplementary Fig. S2). The only full-length sequence of $S$. antarcticum was recently submitted to GenBank (strain 6B1Y; GenBank accession number AJ576248) and it is almost identical to that of Pedobacter piscium (differing only by one gap and one unidentified nucleotide), indicating that the taxonomic status of this species should be re-examined. Steyn et al. (1998) reported that the misclassified species Flexibacter canadensis was located at the border of the genera Sphingobacterium and Pedobacter; however in our study, F. canadensis was placed in a separate branch of the phylogenetic tree with maximum bootstrap support (Fig. 1), thus questioning its taxonomic position within the family Sphingobacteriaceae. 'Candidatus comitans', which was not grown in pure culture, was proposed to be a member of the genus Sphingobacterium rather than Pedobacter (Jacobi et al., 1996; Steyn et al., 1998); however, the phylogenetic position of 'Candidatus comitans', based on the 16S rRNA gene sequence analysis performed in this study, was within the cluster formed by Pedobacter species (Fig. 1).

Yabuuchi et al. (1983) proposed the genus Sphingobacterium, the type genus of the family Sphingobacteriaceae, to accommodate some previously described members of the genus Flavobacterium with DNA $\mathrm{G}+\mathrm{C}$ contents of 39-42 mol\%. Strain AW-6 ${ }^{\mathrm{T}}$ has a DNA G $+\mathrm{C}$ content $(45.6 \mathrm{~mol} \%)$ slightly higher than that of recognized members of the family Sphingobacteriaceae (36.9$44.2 \mathrm{~mol} \%$; Steyn et al., 1998). The closest match to strain AW $-6^{\mathrm{T}}$ based on DNA G $+\mathrm{C}$ content was $S$. thalpophilum (44.0-44.2 mol\%). Steyn et al. (1998) reported that the genus Sphingobacterium is genotypically heterogeneous, with S. thalpophilum (the closest recognized species to strain AW$6^{\mathrm{T}}$ within the family Sphingobacteriaceae) being its most remote species. In addition, a low $(<70 \%)$ level of DNADNA relatedness (33.8-37.0\%) was observed between strain AW $-6^{\mathrm{T}}$ and S. thalpophilum DSM $11723^{\mathrm{T}}$. Menaquinone-7 was detected in the respiratory chain of strain AW- $6^{\mathrm{T}}$, a common characteristic of members of the family Sphingobacteriaceae (Yabuuchi et al., 1983; Steyn et al., 1998; Shivaji et al., 2005).

Based on 16S rRNA gene sequencing, the phylogenetic position of strain AW- $6^{\mathrm{T}}$ among members of the family Sphingobacteriaceace was unique and distinct (Fig. 1).
Construction of phylogenetic trees using distance-matrix, character-based (parsimony) and maximum-likelihood methods all placed strain $\mathrm{AW}-6^{\mathrm{T}}$ together with clone BIti35 (89.7\% 16S rRNA gene sequence similarity) into a separate cluster, distinct from any recognized member of the family Sphingobacteriaceace. Clone BIti35 was obtained from a waste-gas-degrading community in an industrial biofilter (Friedrich et al., 2002), while isolates PF-H (GenBank accession number DQ207363) and BPC8, other phylogenetic relatives (but still distinct) of strain $\mathrm{AW}-6^{\mathrm{T}}$, were isolated from Kartchner Caverns, Arizona, and a contaminated soil (Kanaly et al., 2002), respectively. Strain AW- $6^{\mathrm{T}}$ was isolated from a sludge-like by-product of the olive-oil extraction industry, showing similarities in this respect to Pedobacter species, which have been isolated from soil/activated sludge and other environmental samples (Steyn et al., 1998; Margesin et al., 2003; Shivaji et al., 2005; Vanparys et al., 2005; Yoon et al., 2006). In contrast, all Sphingobacterium species [apart from S. antarcticum (the taxonomic position of which needs to be reconsidered)] have been recovered from clinical specimens (Yabuuchi et al., 1983; Steyn et al., 1998).

This is the first report of a non-halotolerant, nonalkalitolerant bacterium isolated from alkaline alpeorujo. Despite the fact that all the previously isolated bacteria reported from alkaline alpeorujo could be effectively adapted to the moderate alkalinity and salinity of this environment (Ntougias et al., 2006), strain AW- $6^{\mathrm{T}}$ failed to tolerate high $\mathrm{pH}$ and salinity. Furthermore, strain AW- $6^{\mathrm{T}}$ was able to grow only in protocatechuate when media containing phenolic compounds as the sole carbon and energy source were tested.

On the basis of the phenotypic, chemotaxonomic and phylogenetic data, we conclude that strain $\mathrm{AW}-6^{\mathrm{T}}$ represents a novel species of a new genus within the family Sphingobacteriaceae, for which the name Olivibacter sitiensis gen. nov., sp. nov. is proposed.

\section{Description of Olivibacter gen. nov.}

Olivibacter [O.li.vi.bac'ter. L. n. oliva olive; N.L. masc. n. bacter a rod; N.L. masc. n. Olivibacter a rod-shaped bacterium from olives/olive processing by-product].

Cells are Gram-negative, non-motile and rod-shaped, developing in irregular, pigmented creamy white colonies. Endospores are not formed. Neutrophilic and non-halotolerant. Mesophilic and strictly aerobic. Oxidase- and catalase-positive. Chemo-organotrophic. Menaquinone-7 is present in the respiratory chain. The major fatty acids are $\mathrm{C}_{16: 1} \omega 7 c$ and/or iso- $\mathrm{C}_{15: 0} 2-\mathrm{OH}$, iso- $\mathrm{C}_{15: 0}$, iso- $\mathrm{C}_{17: 0} 3-\mathrm{OH}$, and $\mathrm{C}_{16: 0}$. The DNA G $+\mathrm{C}$ content is $45.6 \mathrm{~mol} \%$. The type species is Olivibacter sitiensis.

\section{Description of Olivibacter sitiensis sp. nov.}

Olivibacter sitiensis [si.ti.en'sis. N.L. masc. adj. sitiensis pertaining to Sitia (north-east Crete, Greece) the vicinity in which the olive-oil mill by-product was obtained]. 
A strict aerobe that does not grow at $3 \%(\mathrm{w} / \mathrm{v}) \mathrm{NaCl}$. The $\mathrm{pH}$ and temperature ranges for growth are $5-8$ and $5-45^{\circ} \mathrm{C}$, respectively. The optimal $\mathrm{pH}$ and temperature for growth are $6-7$ and $28-32{ }^{\circ} \mathrm{C}$, respectively. Tween 20 is not hydrolysed. Utilizes mostly $\mathrm{D}(+)$-glucose, protocatechuate and $\mathrm{D}(+)$-xylose $\left(\mathrm{OD}_{600}\right.$ in the range $\left.0.13-0.35\right)$, followed by L-cysteine, $\mathrm{D}(-)$-fructose, $\mathrm{D}(+)$-galactose, L-histidine, lactose, sorbitol and sucrose $\left(\mathrm{OD}_{600}\right.$ in the range $\left.0.05-0.12\right)$. Acetate, $\mathrm{D}(+)$-cellobiose, cinnamate, citrate, ethanol, ferrulate, gallate (no growth was observed on solid medium), L-glutamine, glycerol, glycine, inositol, L-isoleucine, L-lysine, maltose, D-mannitol, L-methionine, phenol, L-proline, L-serine, starch, succinate, syringate, Ltryptophan, vanillate and $o$-vanillin are not utilized. Susceptible to ampicillin, bacitracin, chloramphenicol, penicillin, rifampicin, tetracycline and trimethoprim, but resistant to kanamycin, polymixin B and streptomycin (each at $50 \mu \mathrm{g} \mathrm{ml}^{-1}$ ).

The type strain, AW $-6^{\mathrm{T}}\left(=\mathrm{DSM} 17696^{\mathrm{T}}=\mathrm{CECT} 7133^{\mathrm{T}}\right)$, was isolated from alkaline alpeorujo in the region of Sitia, Crete, Greece.

\section{Acknowledgements}

This work was partially funded by the EPAN-FP66 project (Greek General Secretariat of Research and Technology). We would like to thank Filotheos Spanoudakis and Manolis Aivaliotis (Toplou Monastery, Viokalliergites Sitias SA) for their kind collaboration throughout this project.

\section{References}

Cashion, P., Holder-Franklin, M. A., McCully, J. \& Franklin, M. (1977). A rapid method for the base ratio determination of bacterial DNA. Anal Biochem 81, 461-466.

Cavalli-Sforza, L. L. \& Edwards, A. W. F. (1967). Phylogenetic analysis. Models and estimation procedures. Am J Hum Genet 19, 233-257.

Chamkha, M., Labat, M., Patel, B. K. C. \& Garcia, J. L. (2001) Isolation of a cinnamic acid-metabolizing Clostridium glycolicum strain from oil mill wastewaters and emendation of the species description. Int J Syst Evol Microbiol 51, 2049-2054.

De Ley, J., Cattoir, H. \& Reynaerts, A. (1970). The quantitative measurement of DNA hybridization from renaturation rates. Eur J Biochem 12, 133-142.

Felsenstein, J. (2004). PHYLIP (phylogeny inference package), version 3.6. Department of Genome Sciences and Department of Biology, University of Washington, Seattle, USA.

Friedrich, U., Prior, K., Altendorf, K. \& Lipski, A. (2002). High bacterial diversity of a waste gas-degrading community in an industrial biofilter as shown by a $16 \mathrm{~S}$ rDNA clone library. Environ Microbiol 4, 721-734.

Gallego, V., García, M. T. \& Ventosa, A. (2006). Pedobacter aquatilis sp. nov., isolated from drinking water, and emended description of the genus Pedobacter. Int J Syst Evol Microbiol 56, 1853-1858.

Huß, V. A. R., Festl, H. \& Schleifer, K. H. (1983). Studies on the spectrophotometric determination of DNA hybridization from renaturation rates. Syst Appl Microbiol 4, 184-192.
Hwang, C. Y., Choi, D. H. \& Cho, B. C. (2006). Pedobacter roseus sp. nov., isolated from a hypertrophic pond, and emended description of the genus Pedobacter. Int J Syst Evol Microbiol 56, 1831-1836.

Jacobi, C. A., Reichenbach, H., Tindall, B. J. \& Stackebrandt, E. (1996). 'Candidatus comitans', a bacterium living in coculture with Chondromyces crocatus (myxobacteria). Int J Syst Bacteriol 46, 119-122.

Jukes, T. H. \& Cantor, C. R. (1969). Evolution of protein molecules. In Mammalian Protein Metabolism, pp. 21-132. Edited by H. N. Munro. New York: Academic Press.

Kämpfer, P. \& Kroppenstedt, R. M. (1996). Numerical analysis of fatty acid patterns of coryneform bacteria and related taxa. Can J Microbiol 42, 989-1005.

Kanaly, R. A., Harayama, S. \& Watanabe, K. (2002). Rhodanobacter sp. strain BPC1 in a benzo[a]pyrene-mineralizing bacterial consortium. Appl Environ Microbiol 68, 5826-5833.

Kluge, A. G. \& Farris, J. S. (1969). Quantitative phyletics and the evolution of the anurans. Syst Zool 18, 1-32.

Koussemon, M., Combet-Blanc, Y., Patel, B. K. C., Cayol, J. L., Thomas, P., Garcia, J. L. \& Ollivier, B. (2001). Propionibacterium microaerophilum sp. nov., a microaerophilic bacterium isolated from olive mill wastewater. Int J Syst Evol Microbiol 51, 1373-1382.

Kroppenstedt, R. M. (1985). Fatty acid and menaquinone analysis of actinomycetes and related organisms. In Chemical Methods in Bacterial Systematics (Society for Applied Bacteriology Technical Series no. 20), pp. 173-199. Edited by M. Goodfellow \& D. E. Minnikin. New York: Academic Press.

Kuykendall, L. D., Roy, M. A., O’Neill, J. J. \& Devine, T. E. (1988). Fatty acids, antibiotic resistance, and deoxyribonucleic acid homology groups of Bradyrhizobium japonicum. Int J Syst Bacteriol 38, 358-361.

Margesin, R., Sproer, C., Schumann, P. \& Schinner, F. (2003). Pedobacter cryoconitis sp. nov., a facultative psychrophile from alpine glacier cryoconite. Int J Syst Evol Microbiol 53, 1291-1296.

Mechichi, T., Labat, M., Garcia, J. L., Thomas, P. \& Patel, B. K. C. (1999). Sporobacterium olearium gen. nov., sp. nov., a new methanethiol-producing bacterium that degrades aromatic compounds, isolated from an olive mill wastewater treatment digester. Int J Syst Bacteriol 49, 1741-1748.

Mesbah, M., Premachandran, U. \& Whitman, W. B. (1989). Precise measurement of the $\mathrm{G}+\mathrm{C}$ content of deoxyribonucleic acid by highperformance liquid chromatography. Int J Syst Bacteriol 39, 159-167.

Miller, L. T. (1982). Single derivatization method for routine analysis of bacterial whole-cell fatty acid methyl esters, including hydroxy acids. J Clin Microbiol 16, 584-586.

Ntougias, S. \& Russell, N. J. (2000). Bacillus sp. WW3-SN6, a novel facultatively alkaliphilic bacterium isolated from the washwaters of edible olives. Extremophiles 4, 201-208.

Ntougias, S. \& Russell, N. J. (2001). Alkalibacterium olivoapovliticus gen. nov., sp. nov., a new obligately alkaliphilic bacterium isolated from edible-olive wash-waters. Int J Syst Evol Microbiol 51, 1161-1170.

Ntougias, S., Zervakis, G. I., Ehaliotis, C., Kavroulakis, N. \& Papadopoulou, K. K. (2006). Ecophysiology and molecular phylogeny of bacteria isolated from alkaline two-phase olive mill wastes. Res Microbiol 157, 376-385.

Rohlf, F. J. (2000). NTSYSpc (Numerical Taxonomy and Multivariate Analysis System), version 2.1. Department of Ecology and Evolution, State University of New York, Stony Brook, NY, USA, and Exeter Software, NY, and Applied Biostatistics Inc., Port Jefferson, NY, USA.

Saitou, N. \& Nei, M. (1987). The neighbor-joining method: a new method for reconstructing phylogenetic trees. Mol Biol Evol 4, 406-425. 
Shivaji, S., Ray, M. K., Rao, N. S., Saisree, L., Jagannadham, M. V., Kumar, G. S., Reddy, G. S. N. \& Bhargava, P. M. (1992). Sphingobacterium antarcticus sp. nov., a psychrotrophic bacterium from the soils of Schirmacher oasis, Antarctica. Int J Syst Bacteriol 42, 102-106.

Shivaji, S., Chaturvedi, P., Reddy, G. S. N. \& Suresh, K. (2005). Pedobacter himalayensis sp. nov., from the Hamta glacier located in the Himalayan mountain ranges of India. Int J Syst Evol Microbiol 55, 1083-1088.

Smibert, R. M. \& Krieg, N. R. (1994). Phenotypic characterization. In Methods for General and Molecular Bacteriology, pp. 607-654. Edited by P. Gerhardt, R. G. E. Murray, W. A. Wood \& N. R. Krieg. Washington, DC: American Society for Microbiology.

Steyn, P. L., Segers, P., Vancanneyt, M., Sandra, P., Kersters, K. \& Joubert, J. J. (1998). Classification of heparinolytic bacteria into a new genus, Pedobacter, comprising four species: Pedobacter heparinus comb. nov., Pedobacter piscium comb. nov., Pedobacter africanus sp. nov. and Pedobacter saltans sp. nov. Proposal of the family Sphingobacteriaceae fam. nov. Int J Syst Bacteriol 48, 165-177.

Takeuchi, M. \& Yokota, A. (1992). Proposals of Sphingobacterium faecium sp. nov., Sphingobacterium piscium sp. nov., Sphingobacterium heparinum comb. nov., Sphingobacterium thalpophilum comb. nov. and 2 genospecies of the genus Sphingobacterium, and synonymy of Flavobacterium yabuuchiae and Sphingobacterium spiritivorum. J Gen Appl Microbiol 38, 465-482.

Tamaoka, J. \& Komagata, K. (1984). Determination of DNA base composition by reversed-phase high-performance liquid chromatography. FEMS Microbiol Lett 25, 125-128.
Ten, L. N., Liu, Q. M., Im, W. T., Lee, M., Yang, D. C. \& Lee, S. T. (2006). Pedobacter ginsengisoli sp. nov., a DNase-producing bacterium isolated from soil of a ginseng field in South Korea. Int J Syst Evol Microbiol 56, 2565-2570.

Tindall, B. J. (1990a). A comparative study of the lipid composition of Halobacterium saccharovorum from various sources. Syst Appl Microbiol 13, 128-130.

Tindall, B. J. (1990b). Lipid composition of Halobacterium lacusprofundi. FEMS Microbiol Lett 66, 199-202.

Van de Peer, Y. \& de Wachter, R. (1993). TREECON: a software package for the construction and drawing of evolutionary trees. Comput Appl Biosci 9, 177-182.

Vanparys, B., Heylen, K., Lebbe, L. \& De Vos, P. (2005). Pedobacter caeni sp. nov., a novel species isolated from a nitrifying inoculum. Int J Syst Evol Microbiol 55, 1315-1318.

Wilson, K. (1992). Preparation of genomic DNA from bacteria. In Short Protocols in Molecular Biology, pp. 2-10-2-11. Edited by F. M. Ausubel, R. Brent, R. E. Kingston, D. D. Moore, J. G. Seidman, J. A. Smith \& K. Struhl. New York: Wiley \& Sons.

Yabuuchi, E., Kaneko, T., Yano, I., Moss, C. W. \& Miyoshi, N. (1983). Sphingobacterium gen. nov., Sphingobacterium spiritivorum comb. nov., Sphingobacterium multivorum comb. nov., Sphingobacterium mizutae sp. nov., and Flavobacterium indologenes sp. nov.: glucosenonfermenting Gram-negative rods in CDC groups IIK-2 and IIb. Int J Syst Bacteriol 33, 580-598.

Yoon, J.-H., Lee, M.-H., Kang, S.-J., Park, S.-Y. \& Oh, T.-K. (2006). Pedobacter sandarakinus sp. nov., isolated from soil. Int J Syst Evol Microbiol 56, 1273-1277. 